\title{
Restructuring State-Owned Enterprises (SOEs) as a Strategy to Face Demonopolization Policies
}

\author{
Putu Samawati \\ Faculty of Law, Sriwijaya University, Palembang, Indonesia. \\ Ph.D. Student, Faculty of Law, Gadjah Mada University, Yogyakarta, Indonesia. \\ E-mail:putusamawati80@gmail.com
}

\begin{tabular}{l} 
ARTICLE INFO \\
\hline Keywords: \\
Restructuring, State- \\
Owned Enterprises, \\
Strengthen Company, \\
Demonopolization. \\
How to cite: \\
Samawati P. \\
Restructuring State- \\
Owned Enterprises \\
(SOEs) as a Strategy to \\
Face Demonopolization \\
Policies. \\
MEDIA HUKUM, +62 \\
274 387656 (Ext. 220$)$ \\
Article History \\
Received: $24 / 01 / 2019$ \\
Reviewed: 01/05/2019 \\
Revised: \\
Accepted: 24/06/2019 \\
\end{tabular}

\begin{abstract}
The demonopolization policy on State-Owned Enterprises (SOEs) makes SOEs as an independent corporations by prioritizing profit motives while running a business for public benefits. The opportunity for private companies to become competitors of SOES that have been running a monopoly business is one of the challenges for SOEs to compete. Restructuring of SOEs is a strategy to survive in business. The fundamental goal to achieve is that SOEs can become the main business entity that plays a role in national development by combining corporate/business principles and public services, but it still rests on the concept of democratic economy as a characteristic of Indonesian. The main problem to improve the role of SOEs in being able to be independent and competitive would be presented through normative juridical (doctrinal) research by using secondary data as the main data. The findings in the normativeprescriptive analysis would then be interacted using qualitative descriptive analysis methods through inductive conclusions. The results is finding an external and internal improvement strategy for the company by strengthening the concept of restructuring as an effort to enhance the role SOEs to be independent, competitive, and contributive to the sovereign, fair, and prosperous national economy.
\end{abstract}

DOI: 10.18196/jmh.20190119

Copyright (C) 2019 MEDIA HUKUM. All rights reserved.

\section{Introduction}

The existence of a State-Owned Enterprises (SOEs) with public character demonstrated by the government was indeed intended to revitalize SOEs to be able to have competitiveness with Private-Owned Enterprises. ${ }^{1}$ Rodriques and Pereira (2011) define

\footnotetext{
${ }^{1}$ Sedlak, M and Roberts, I. (1991). “An Inevitable Part of Economic Reform: Demonopolization and the Development of Economic Competition". Soviet and Eastern European Foreign Trade Journal, 27(2): 55. http://www.jstor.org/stable/2774925.
} 
demonopolization as a condition of SOEs that originally obtained monopoly rights in conducting businesses in vital sectors, then these rights were revoked through legislation, thus allowing the private sector to establish the same type of SOEs businesses. Creating a new competitor in running a business that has been monopolized is a step that is expected so that SOEs can improve their performance. ${ }^{2}$

There are concerns when the demonopolization policy is implemented, namely the issue of protection of state assets and protection of fulfilling the lives of many people which is mandated in Article 33 of the 1945 Indonesian Constitution. Anggoro (2016) argues that there are at least two structured efforts assumed to weaken the role of the state in economy with the enactment of a demonopolization policy on SOEs. First, foreign investment is given a wide opportunity to be implemented in various strategic and vital sectors of the Indonesian economy. Second, providing opportunities for private business entities to compete with SOEs even for goods that have a public character. ${ }^{3}$ The effect of neo-liberal economics is considered as a factor that has pushed the government to enact the demonopolization policy on SOEs. ${ }^{4}$ On the other hand, some assumptions assuming a democratic/populist economic system is gradually abandoned on the grounds of globalization/free market pressure.

Demonopolization policy by the government is an effort to encourage the private sectors to become a business competitor for SOEs. The aim is to improve the performance of the companies that compete healthily and improve their service to consumers/society to create a perfectly competitive market. ${ }^{5}$ The point is that the state has five functions of the right to control which are confirmed in the Decision of Constitutional Court No.002/PPU-I/2003 namely, a policy maker (beleid), carrying out management actions (bestuursdaad), making arrangements (regelendaad), conducting management (beheersdaad), and supervision (toezichthoudensdaad). These five functions can be implemented in the form of an external and internal improvement strategy of the company by strengthening the concept of restructuring to survive from the demonopolization policy, as an effort to increase the role of SOEs to be able to be independent, competitive, and contributive to the national economy.

Demonopolization is a policy that can be done by the government as a commitment to the free market which the World Trade Organization (WTO) expects. That policy becomes a serious problem for SOEs to be in a comfortable zone for a long period, especially for the SOEs to have monopoly rights. Restructuring SOEs is expected to help strengthen companies. The main problem to be discussed was how to increase the role of SOEs to be able to be independent and competitive with the private sectors, but on the other side, it should be an agent of development. This main issue would be elaborated further by describing the ideal concept of demonopolization of SOEs based on the democratic economic system, including the issue of regulation and the strategy of the policy of demonopolization as an effort to guarantee the stability of national development.

\footnotetext{
${ }^{2}$ Rodriques, A and Pereira, P. (2011). “Investment Decisions in Granted Monopolies Under the Threat of a Random Demonopolization.” Economic Journal Faculty of Economic University of Parto Portugal. 32(1): 2. https:www.semanticscholar.org/paper/Investment-Decisions-in-Granted-Monopolies-Under-ofRodrigues-Pereira

${ }^{3}$ Anggoro, T. (2016). Monopoli Alamiah Badan Usaha Milik Negara. Depok: Herya Media, p. 126.

${ }^{4}$ Gie, K.K. (1998). Praktek Bisnis dan Orientasi Ekonomi Indonesia. Jakarta: Gramedia Pustaka Utama \& IBBI, p.36.

${ }^{5}$ Stiglizt, J.E. (2007). Making Globalization Work: Menyiasati Globalisasi Menuju Dunia yang Lebih Adil. Transleted by Edrijani Azwaldi. Bandung: Mizan, p.135.
} 


\section{Method}

\subsection{Type of Research}

This research was normative legal research. ${ }^{6}$ The aim was to answer the problems in terms of legal principles and norms characterizing the rationalization of demonopolization policies and functions of SOEs as agents of development by linking these policies in applicable laws to social order. ${ }^{7}$ The statute approach was the key to analysis in addition to the legal history approach and the philosophical approach.

\subsection{Data Collection}

The technique of collecting data in this study used secondary data, obtained from literature/documentary study. ${ }^{8}$ The collected data were then processed by classifying the facts and the legal issues under investigation and finally resulted in legal analysis. ${ }^{9}$

\subsection{Analysis}

The data analysis was carried out using the doctrinal method through prescriptive optics. ${ }^{10}$ The result of the analysis concluded a new concept that answered the problem inductively to provide an understanding of the concept of demonopolization as an effort to strengthen the role of SOEs in sustainable national development. ${ }^{11}$

\section{Analysis and Results}

Law is defined as a set of rules intending to regulate life in a community in a certain time in an orderly manner. ${ }^{12}$ The main purpose of the law is to achieve justice, create legal certainty, and provide benefits to the community. ${ }^{13}$ The practice of law cannot stand alone; its existence is influenced by the economic and political sciences, especially in developing countries such as the third world countries. The role of law in development has a very important position, to be noted that the role of law will differ from one community group to another. Also, it is influenced by the last mass, the current mass, or the coming masses, as expressed by Sunaryati Hartono. ${ }^{14}$ The further assertion was stated by Achmad Ali (1996) that the role of law is hardly influenced by changes in society from time to time, which need more attention that the law always plays a role in changing society to improve society to have a better life. ${ }^{15}$

The existence of law in the nation's economic development is seen by the enactment of legal rules in the form of legislation. The rules outlined in the form of legislation constitute an implementation to provide legal protection for parties bound in development activity. Legal protection is a central point that becomes a focus in aspects of economic development activities to achieve a sense of justice. Abdulkadir

\footnotetext{
${ }^{6}$ Soekanto, S. and Abdurrahman, H. (2003). Metode Penelitian Hukum. Jakarta: Rineka Cipta, p. 112.

${ }^{7}$ Sidharta, B.A. (2001). Filsafat Ilmu Hukum. Bandung: Laboratorium Hukum Fakultas Hukum Universitas Khatolik Parahyangan, p. 23.

${ }^{8}$ Soekanto, S and Mamudji, S. (2006). Penelitian Hukum Normatif. Jakarta: Rajawali, p. 10.

${ }^{9}$ Hartono, S. (1994). Penelitian Hukum di Indonesia Pada Akhir Abad ke-20. Bandung: Alumni, p. 44.

${ }^{10}$ Muhadjir, N. (1998). Metodologi Penelitian Kualitatif. Yogyakarta: Rake Sarasin, p. 29.

${ }^{11}$ Sunggono, B. (2007). Metodologi Penelitian Hukum. Jakarta: Raja Grafindo Persada, p. 10.

12 Saidin, O.K. (2016). Mencari dan Menjadi Hukum Indonesia: Refleksi Pemikiran Prof. Mahadi. Jakarta: RajaGrafindo Persada, p. 3.

${ }^{13}$ Manan, A. (2013). Aspek-aspek Pengubah Hukum. Jakarta: Kencana Prenada Media Group, p. 64-65.

${ }^{14}$ Hartono, S. (1998). Hukum Pembangunan Ekonomi Pembangunan Indonesia. Bandung: Bina Cipta, p. 18-19.

${ }^{15}$ Ali, S. (1996). Menguak Tabir Hukum: Suatu Kajian Filosofis dan Sosiologis. Jakarta: Kencana, p. 215.
} 
Muhammad states that legal protection is an effort regulated by the law to prevent violations by unauthorized persons. The essence of law exists if there is a conflict of human interest. This condition occurs when carrying out its interests or meeting its needs, someone harms another. At the time of the emergence of this conflict, man feels the need for an effort to protect himself/herself through a provision known as the law. This can be assumed to result in creating a legal protection concept. ${ }^{16}$

Based on that statements, it can be argued that the concept of legal protection in this study is legal protection against the role of a demonopolized SOEs, as an agent of development whose performance is intended to protect important branches of production for the state and control the livelihoods of many people, with the main aim of guaranteeing Indonesian natural resources and the welfare of the Indonesian people as a whole. The hope is to provide opportunities for SOEs to be more advanced, developed, and able to compete with the private sectors in improving their service quality to the public in general.

\subsection{The Ideal Concept of SOEs Demonopolization Based on the Democratic Economic System.}

SOEs is a business entity whose entire or part of its capital is owned by the state through direct participation derived from separated state assets (Article 1 Point 1 of Law No. 19 of 2003 concerning State-Owned Enterprises). The definition of SOEs can be interpreted that SOEs are equal to companies because they refer to the term of business entity. In contrast to companies in general, the establishment of state-owned enterprises is aimed at not only gaining a profit but also trying to contribute to the economic development of the Indonesian people orienting to improve the welfare of many people. This social function is a characteristic that distinguishes the SOEs from the other types of companies. ${ }^{17}$

The performance of SOEs is indeed directed to gain profits and be able to meet the needs of many people. The burden as an agent of development does indeed place the SOEs to be able to compete with the private sectors. The demands of globalization have also become a major influence on the government policies waiting for the business sectors that have been monopolized by the SOEs to be handed over to the private sectors. For the sake of efficiency and effectiveness, the government, through the issuance of legislation, relinquished the SOEs monopoly rights with the following conditions as follows:

a. The SOEs runs business activities in the business sector managing or distributing goods and services characterized as public goods or services; ${ }^{18}$

b. The SOEs operates vital sectors that are important for the state and controls the livelihoods of many people (Indonesian Constitutional Court, Decision No. 36/PUU-X/2012. Judicial review of Law No. 22 of 2001 concerning Oil and Gas);

c. The business activities carried out by the SOEs are targeted to fulfill public needs or public benefits (Article 5, Law No. 25 of 2009 concerning Public Utility).

\footnotetext{
${ }^{16}$ Mertokusuma, S. (2002). Mengenal Hukum. Yogyakarta: Liberty, p. 31.

${ }^{17}$ Ilmar, A. (2012). Hak Menguasai Negara dalam Privatisasi BUMN. Jakarta: Kencana Prenada Media Group, p. 77.

${ }^{18}$ Anggoro, T. Op. Cit., p. 126.
} 
In particular, the SOEs having a public character must be considered to implement the demonopolization policy, because this type of SOEs has an impact on meeting the needs of many people.

SOEs were established as an agent of development to be more oriented to the fulfillment of public utility. ${ }^{19}$ This differentiates it from private companies that are only profit-oriented (profit motives). The policy of demonopolization of SOEs imposed by the government basically must rest on the concept of economic democracy. The practice of implementing the democratic economic system is that every member of the community must not be treated as an object; every member of the community must be treated as a subject. The position of community members as the subject of the economy has broad consequences for the implementation of a democratic economic system. In this case, the people must be able to play an active role not only as participatory but also be emancipatory. ${ }^{20}$ Community members must be used as a motor or supporter of development, through efforts to build the capacity of the community to have coownership, capability, and participation in making co-determinating decisions, and bearing all the consequences arising from the implementation of economic decisions (co-responsibility). The hope is that the condition of the community can implement the economic system in a free atmosphere and arouse the dynamics and creativity of the people. ${ }^{21}$

The term of "Economic Democracy" refers to the populist economy. This is also related to the fourth principle of Pancasila, which uses the populist word.22 An important point of concern is that the populist economy is not the same as the people's economy or pro-people's economy, which is interpreted to be too narrow in the scope of certain groups. The populist word refers to a broader sector that reaches all Indonesian people as a whole by placing a pattern of management, distribution, and utilization of the people, by the people and for the people. ${ }^{23}$ Participation of all members of the community is a form of people's involvement in ensuring the utilization of national resource potential, and the form of community participation in utilizing national products. The main objective is to be able to realize a decent life for all Indonesian people and improve the welfare of society materially and spiritually according to the opening of the fourth paragraph of the 1945 Indonesian Constitution.

In Article 33 of the 1945 Indonesian Constitution, the Indonesian economy is based on economic democracy which is carried out with the principle of togetherness, fairefficiency, sustainability, environmentalism, independence, and by maintaining a balance, progress and national economic unity which guarantees justice and prosperity of the people. ${ }^{24}$ The meaning of economic democracy is relevant to the meaning of democracy in Indonesia. The Indonesian democracy is based on a consensus (agreement) called "Vertrag", based on the togetherness (kolektiviteit) and family principle. Regarding the concept of Indonesian democracy, Bung Karno (1945) proposes that the desired democracy is life-giving consultations, namely politiek-

\footnotetext{
${ }^{19}$ Ilmar, A, Op. Cit. p. 73

${ }^{20}$ Swasono, S.E. (2008). Kesokoguruan Ekonomi Rakyat dan Triple-Co. Harian Umum Suara Pembaharuan, Jakarta, 14 Juli 2008, p. 6.

${ }^{21}$ Sumawinata, S. (2004). Politik Ekonomi Kerakyatan. Jakarta: Gramedia Pustaka Utama, p. 60-61.

${ }^{22}$ Asshiddiqie, J. (2010). Konstitusi Ekonomi. Jakarta: Kompas, p. 70.

${ }^{23}$ Baswir, R. (2010). Manifesto Ekonomi Kerakyatan. Yogyakarta: Pustaka Pelajar, p. 10.

${ }^{24}$ Prasetyo, K.F. (2012). "Politik Hukum di Bidang Ekonomi dan Pelembagaan Konsepsi Welfare State di dalam Undang-undang Dasar 1945". Journal Konstitusi 9(3): 503. https:/ /doi.org/10.31078/jk\%25x
} 
ecconomische democracy which can bring social welfare, which is not only in the politic equation but also in the economic field. There must be equal to mean the best welfare and rights for all. ${ }^{25}$

According to the concept of Mohammad Hatta (1956), Article 33 of the 1945 Indonesian Constitution is the main joint for Indonesia's political economy and social politics. ${ }^{26}$ Because of Article 33, the basis of a regular economy is concluded to overcome poverty a development implementation program that is based on the people's economy carried out as a joint venture and must be done in a family manner. The basis of economic democracy (based on the Explanation of Article 33 of the first paragraph of the 1945 Constitution), is production carried out by all, for all, under the leadership or ownership of members of society. It is the prosperity of the community to be prioritized, not the prosperity of one person. Therefore, the economy is a structure of a joint effort based on the principle of kinship.

The essence of the implementation of the Indonesian economy is an economy that places the Indonesian people as the main sovereign parties. The sovereignity of the people in the Indonesian economic system is expressly outlined in national policies to carry out "economic transformation and social transformation". The economic transformation changes the colonial economic system, which is subordinated to a democratic national economic system. The social transformation changes the pattern of subordinate economic relations such as master-servant; laborers are transformed into democratic economic relations, namely the pattern of participatory and emancipatory economic relations. The participatory meaning and emancipatory economy are the implementations of the principle of "participation" in the development process. The economic progress of the people must be inherent with the progress of national development. In every development progress, the people who are under it must be lifted and supervised.27

In addition to the meaning of the economy based on the principle of kinship, another meaning refers to the meaning of the concept of "mastering important branches of production for the state and dominating the livelihood of many people controlled by the state". This concept is a form of realization of the role of government in the national economic order through the establishment of SOEs. The establishment of SOEs is a form of government service to the public not as an effort to control the economic system completely, let alone used as a tool to extract wealth for the state and privately (Part of Consideration in Law No. 19 of 2003 concerning SOEs).

The justification for the demonopolization policy of SOEs can be linked to the concept of being controlled by the state according to Mohammad Hatta (1970), stating that "controlled by the state" does not mean that the state itself becomes an entrepreneur, but it is enough if the state power is in making regulations in order to improve the economy. ${ }^{28}$ Regarding the issue of being controlled by the state, Emil Salim (1985) argues that the term controlled by the state has the meaning as; owner, regulator,

\footnotetext{
${ }^{25}$ Soekarno. (2003). Lahirnya Pantja-Sila: Pidato Pertama Tentang Pancasila. Blitar: Departemen Penerangan Republik Indonesia, p. 22-23.

${ }^{26}$ Damanik, E. D. (1985). Kemakmuran Masyarakat Berdasarkan Koperasi dalam Membangun Sistem Ekonomi Nasional: Sistem Ekonomi dan Demokrasi Ekonomi. Jakarta: UI Press, p. 46.

${ }^{27}$ Swasono, S.E. (2005). Ekspose Ekonomi: Mewaspadai Globalisme dan Pasar Bebas. Yogyakarta: Pustep UGM, p. 9.

${ }^{28}$ Baswir, R. Op. Cit., p. 31-32.
} 
planner, implementer, and supervisor. ${ }^{29}$ The formulation of these five meanings with different values can put the state in its position to master it can by owning and directly managing important branches of production and natural resources. Other things the state can do are holding the sovereignty, utilizing the part of the regulation, planning, and supervising the field. This view puts the government to play a role by the situation and conditions of the development era which always requires adjustments to follow the direction of global policy that wants a free market without any restrictions and obstacles in doing it. The basic concern of the government is the problem of the guaranteeing the protection of the fulfillment of the needs of many people in life and the protection of the existence of Indonesia's sustainable natural wealth.

The realization of the concept of demonopolization of SOEs based on the principle of economic democracy is to strengthen the basic goal of establishing SOEs with internal reform and the externalization of SOEs institutions so that their role as agents of development can be realized. The other main thing is that the government has to give the first opportunity to indigenous private enterprises to become competitors for SOEs. This is done as an effort to restore the benefits of processing Indonesia's human resources and natural resources to the Indonesian people themselves. The last option is to provide opportunities for private investors to become competitors of SOEs by stipulating the rules for implementing business activities based on the state policies that are strengthened in the legislation. State functions are positioned as policymakers, regulator, and supervisor of the private business entities that are competitors of SOEs.

\subsection{Strategy for Enforcing SOEs Demonopolization in Supporting a Sustainable National Economy}

Restructuring is a corporate strategy to improve performance by re-arranging corporate components so that the corporate future has a better performance. Article 1 Point 11 of Law No. 19 of 2003 concerning SOEs, provides the meaning of restructuring as an effort carried out in the context of restructuring SOEs, which is one of the strategic steps to improve the internal condition of the company to increase performance and value of its company. The form of restructuring that is possible base on Law No. 40 of 2007 concerning Limited Liability Company can be in the form of merger, consolidation, takeover, and separation of state. The emergence of a decision to restructure occurred due to a shift in the company's strategy. The company designed a corporate strategy by creating a competitive advantage based on the company's internal and external conditions. Based on the Regulation of SOEs Ministry of the Republic of Indonesia No. PER-1/MBU/07/2015 concerning Organization and Good Corporate Ministers of SOEs, Article 211-221, the scope of the restructuring carried out with the company can be implemented in the forms of:

a. Increasing intensity of business competition, especially in the sectors that have monopolies, both regulated and natural monopolies;

b. Structuring functional relations between the government as a regulator and SOEs as a business entity, including the application of the principles of good corporate governance and establishing the direction in the framework of implementing public service obligations; and

\footnotetext{
${ }^{29}$ Swasono, S.E. (ed). (2010). Membangun Sistem Ekonomi Nasional- Sistem Ekonomi dan Demokrasi Ekonomi. Jakarta: UI Press, p. 61
} 
c. The internal restructuring that includes finance, organization/management, operations, systems, and procedures.

The government, as a state representative, must carry out the state duties, including organizing public services. SOEs is a government tool used to support the country's duty in the success of development because the role of SOEs as agents of development is different from than that of a general company. SOEs, as agents of development, are required to be able to carry out vital businesses and the construction of certain projects that are not contained in the original development plan. ${ }^{30}$ The demands of SOEs to be able to be independent and competitive with the private sector are carried out to open up competitive markets globally. On this basis, a strengthening strategy is needed for the role of SOEs to be able to support a sustainable national economy. Internal and external institutional arrangement of SOEs is an important point before the government enacts the demonopolization policy.

Corporatization is one way to improve the role of SOEs through restructuring management by building a corporate culture and utilization of professionals in the management and ownership of the company's shares in the hands of the state. ${ }^{31}$ The essence of corporatization is to in-corporate/business elements and enthusiasm into the SOEs environment, so that these SOEs are managed by the business principles that will lead to competition and encourage the spirit of their managers to achieve the founding goals and earn profits for the development of the SOEs themselves. According to Clarke (2003), the success of SOEs is highly dependent on the application of corporatization of SOEs. This stars from the determination of the right form of stateowned enterprises to the placement of managers of professional corporate organs. ${ }^{32}$ Further confirmation of the corporatization is pointed out by Thynee (1996), that corporatization is the best choice in a SOEs restructuring effort because the role of SOEs that must provide public needs cannot be left to the market mechanism. ${ }^{33}$ Also, the government needs SOEs to increase capacity to ensure stability and availability of important goods and services for the people.

This corporatization is in the form of internal SOEs strengthening the effort focusing on improving the law, the purpose of establishing, determining the form of the company, internal organization, management, and SOEs management resources. ${ }^{34}$ The concern for Indonesian SOEs is the need to affirm a clear separation between the duties and authorities of the government on SOEs. The government is only limited to shareholders and does not interfere in SOEs management as a corporate entity. ${ }^{35}$ In practice, management can concentrate fully without government interference in carrying out

\footnotetext{
${ }^{30}$ Hartini, R. (2017). BUMN Persero: Konsep Keuangan Negara dan Hukum Kepailitan di Indonesia. Malang: Setara Press, p. 40.

${ }^{31}$ Ruru, B. (1996). “Arah Kebijakan BUMN: Menghadapi Era AFTA dan APEC 2010.” Jurnal Keuangan dan Moneter. Jakarta: Badan Kebijakan Fiskal, p. 16.

${ }^{32}$ Howson, N. (2017). "China's Corporatization Without Privatization and the Late 19th Century Roots of a Stubborn Path Dependency." Vanderbilt Journal of Transnational Law, 50(4): 965, https:/ / repository.law.umich.edu/articles/2021

${ }^{33}$ Thynne, I. (1996). Corporatization as a Strategy of State-Owned Enterprise Reform In. Yuen Ng. Chee at.all. (ed). State Owned Enterprises Reform in Vietnam: Lessons from Asia. Singapore: Institute of Southeast Asian Studies, p. 138.

${ }^{34}$ Simatupang, D.P. (2011). Paradoks Rasionalitas Perluasan Ruang Lingkup Keuangan Negara dan Implikasinya terhadap Kinerja Keuangan Pemerintah. Jakarta: Badan Penelitian FH-UI, p.319.

${ }^{35}$ Haris, A. (2001). 7 Pilar Perusahaan Unggulan: Implementasi Kriteria Baldrige untuk Meningkatkan Kinerja Perusahaan. Jakarta: Gramedia Pustaka, p.4-5.
} 
business based on economic principles and can face global competition. The purpose is to make SOEs as efficient companies so that they have high productivity to be able to compete globally. ${ }^{36}$ The hope is that SOEs can be a balance between economic actors.

The implementation of the restructuring of SOEs should be carried out based on the principle agent principle, where the management of SOEs will do their best to provide the best performance by the principles of the agreement in the relationship between the owner (principal) and management (agent). Thomas (1993) state that there are three main objectives of the corporation according to the principal agent principle, namely: ${ }^{37}$

1) Understanding the management level of the SOEs for the company's main purpose, whose direction is to know the limits of its rights and authority in SOEs;

2) Direction of SOEs has the authority to make important decisions that bring together the company's main objectives;

3) Increasing reward and sanction management system as an incentive to achieve performance.

Based on the principle of the principal agent, the corporatized duties and responsibilities of SOEs management will be clearer, and conflict with the interests and political goals of the government will not be mixed with the interests and objectives of the business. The Board of Directors has the authority and autonomy in managing the company, and the government only functions as a supervisor. SOEs management performance will always be controlled by both the government and private auditors. Management would manage the company to the fullest because there are mechanisms of sanctions and incentives as a driving force to improve the performance of the management. 38 Similarly, Anggoro (2016) supports the mechanism of the corporatization of SOEs because it can create a business environment and conditions that provide opportunities for SOEs to succeed as economic actors. ${ }^{39}$

Strengthening SOEs institutions that are also part of the restructuring is the application of Good Corporate Governance (GCG), to encourage the creation of an efficient, transparent, and consistent market with laws and regulations, as well as building the synergy relationship among the government as a regulator, the world business as market participants, and the community as users of products/services. ${ }^{40}$ There are five principles in implementing GCG, namely transparency, accountability, responsibility, independence, and obligations and equality. ${ }^{41}$ The implementation of the principal agent and GCG principles in the corporatization of SOEs is an effort to strengthen the internal SOEs institutions which will have an extensive impact on the of the SOEs in improving people's welfare. This is because the state would impose the SOEs as a legal entity that carries out corporate principles but still contributes to fulfilling public needs with the realization of profits obtained by the SOEs entering the state treasury and the profits are reinvested by the government for the people's prosperity.

\footnotetext{
${ }^{36}$ Peterson, W.L. (2009). Principle of Economics (Micro). Illinois: Irwin, p. 181.

${ }^{37}$ Thomas, C and Pitelis, C (ed.). (1993). The Political Economy of Privatization. USA: Routledge, p. 315.

${ }^{38}$ Agosto, M. (2005). "The OECD Principles of Good Corporate Governance". Organization of Economic Cooperation and Development, p. 190. http://www.cya.unam.mx/index.php/cya/article/view/562/560

39 Anggoro, T. Op. Cit, p. 513.

${ }^{40}$ Komite Nasional Kebijakan Governance. (2006). Pedoman Umum Good Corporate Governance Indonesia. Jakarta: KNKG, p. 3.

${ }^{41}$ ibid, p. 5-7
} 


\section{Conclusion and Suggestion}

\subsection{Conclusion}

The restructuring of SOEs is one form of strengthening the position of SOEs as corporations and agents of development to get out of their comfort zones, especially those that have been running a monopoly business. Demonopolization policy which is creates competitors for SOEs, making the SOEs strive to strengthen their institutions through restructuring, by implementing the principle agent and good corporate governance. The hope is that they can synergize the profitability of the motives and the beneficiaries of the community. The main thing about implementing the policy of demonopolization and strengthening of SOEs institutions is the ability to create a network among the government as a regulator, the business world as a market player, and the community as users of products/services. The national development using the concept of economic democracy combines the principles of togetherness, fairefficiency, sustainability, environmental insight, and independence, and maintaining a balance, progress and national economic unity whose direction guarantees justice and the greatest prosperity of the people. Restructuring the SOEs is an effort to make them healthier in operating the company efficiently, transparently, and professionally.

\subsection{Suggestion}

The demonopolization policy on SOEs with public characteristics carried out by the Indonesian government can be a motivation for the SOEs to improve performance by improving their institutional management. The ability of SOEs to restructure their corporations to compete with private companies must get special support from the government because the double burden attached to the SOEs is to pursue profits as well as development agents providing benefits to the people. The government support can be done in two ways of increasing the role of SOEs, namely by improving government policies related to the regulation on demonopolization mechanisms and supporting the mechanism of the corporatization of the SOEs.

\section{Acknowledgments}

The author wishes to show gratitude to the Directorate General of Research and Development, Ministry of Research, Technology, and Higher Education Republic of Indonesian for Financial Supported on The Research. Best honor to Dr. Febrian (Dean Faculty of Law, Sriwijaya University) and Prof. Dr. Sigit Riyanto (Dean Faculty of Law, Gadjah Mada University), who has supported my study. I would also like to show my gratitude to Prof. Dr. M. Hawin (promotor) and Prof. Dr. Sulistiowati (co-promotor) for sharing his experience and comments to make my research complete.

\section{References}

Books:

Ali, S. (1996). Menguak Tabir Hukum: Suatu Kajian Filosofis dan Sosiologis. Jakarta: Kencana.

Anggoro, T. (2016). Monopoli Alamiah Badan Usaha Milik Negara. Depok: Herya Media. Asshiddiqie, J. (2010). Konstitusi Ekonomi. Jakarta: Kompas.

Baswir, R. (2010). Manifesto Ekonomi Kerakyatan. Yogyakarta: Pustaka Pelajar. 
Damanik, E. D.. (1985). Kemakmuran Masyarakat Berdasarkan Koperasi dalam Membangun Sistem Ekonomi Nasional: Sistem Ekonomi dan Demokrasi Ekonomi. Jakarta: UI Press.

Gie, K.K. (1998). Praktek Bisnis dan Orientasi Ekonomi Indonesia. Jakarta: Gramedia Pustaka Utama \& IBBI.

Haris, A. (2001). 7 Pilar Perusahaan Unggulan: Implementasi Kriteria Baldrige untuk Meningkatkan Kinerja Perusahaan. Jakarta: Gramedia Pustaka.

Hartini, R. (2017). BUMN Persero: Konsep Keuangan Negara dan Hukum Kepailitan di Indonesia. Malang: Setara Press.

Hartono, S. (1998). Hukum Pembangunan Ekonomi Pembangunan Indonesia. Bandung: Bina Cipta. (1994). Penelitian Hukum di Indonesia Pada Akhir Abad ke-20. Bandung: Alumni.

Ilmar, A. (2012). Hak Menguasai Negara dalam Privatisasi BUMN. Jakarta: Kencana Prenada Media Group.

Komite Nasional Kebijakan Governance. (2006). Pedoman Umum Good Corporate Governance Indonesia. Jakarta: KNKG.

Manan, A. (2013). Aspek-aspek Pengubah Hukum. Jakarta: Kencana Prenada Media Group.

Mertokusuma, S. (2002). Mengenal Hukum. Yogyakarta: Liberty.

Muhadjir, N. (1998). Metodologi Penelitian Kualitatif. Yogyakarta: Rake Sarasin.

Peterson, W.L. (2009). Principle of Economics (Micro). Illinois: Irwin.

Saidin, O.K.. (2016). Mencari dan Menjadi Hukum Indonesia: Refleksi Pemikiran Prof. Mahadi. Jakarta: Raja Grafindo Persada.

Sidharta, B.A. (2001). Filsafat Ilmu Hukum. Bandung: Laboratorium Hukum Fakultas Hukum Universitas Khatolik Parahyangan.

Simatupang, D.P. (2011). Paradoks Rasionalitas Perluasan Ruang Lingkup Keuangan Negara dan Implikasinya Terhadap Kinerja Keuangan Pemerintah. Jakarta: Badan Penelitian FH-UI.

Soekanto, S and Mamudji, S. (2006). Penelitian Hukum Normatif. Jakarta: Rajawali.

Soekanto, S. and Abdurrahman, H. (2003). Metode Penelitian Hukum. Jakarta: Rineka Cipta.

Soekarno. (2003). Lahirnya Pantja-Sila: Pidato Pertama Tentang Pancasila. Blitar: Departemen Penerangan Republik Indonesia.

Stiglizt, J.E. (2007). Making Globalization Work: Menyiasati Globalisasi Menuju Dunia yang Lebih Adil. Transleted by Edrijani Azwaldi. Bandung: Mizan.

Sumawinata, S. (2004). Politik Ekonomi Kerakyatan. Jakarta: Gramedia Pustaka Utama.

Sunggono, B. (2007). Metodologi Penelitian Hukum. Jakarta: Raja Grafindo Persada.

Swasono, S.E. (2005). Ekspose Ekonomi: Mewaspadai Globalisme dan Pasar Bebas. Yogyakarta: Pustep UGM.

(2010). Membangun Sistem Ekonomi Nasional- Sistem Ekonomi dan Demokrasi Ekonomi. Jakarta: UI Press.

Thomas, C and Pitelis, C (ed.). (1993). The Political Economy of Privatization. USA: Routledge.

Thynne, I. (1996). Corporatization as a Strategy of State-Owned Enterprise Reform In. Yuen Ng. Chee at.all. (ed). State Owned Enterprises Reform in Vietnam: Lessons from Asia. Singapore: Institute of Southeast Asian Studies. 


\section{Journal articles:}

Agosto, M. (2005). The OECD Principles of Good Corporate Governance. Organization of Economic Co-operation and Development. http://www.cya.unam.mx/index.php/cya/article/view/562/560.

Howson, N. (2017). "China's Corporatization Without Privatization and the Late 19th Century Roots of a Stubborn Path Dependency." Vanderbilt Journal of Transnational Law, 50(4), https:// repository.law.umich.edu/articles/2021.

Prasetyo, K.F. (2012). "Politik Hukum di Bidang Ekonomi dan Pelembagaan Konsepsi Welfare State di dalam Undang-undang Dasar 1945." Journal Konstitusi 9(3). https://doi.org/10.31078/jk\%25x

Rodriques, A and Pereira, P. (2011). “Investment Decisions in Granted Monopolies Under the Threat of a Random Demonopolization." Economic Journal Faculty of Economic University of Parto Portugal, 32(1). https:www.semanticscholar.org/paper/Investment-Decisions-in-GrantedMonopolies-Under-of-Rodrigues-Pereira

Ruru, B. (1996). "Arah Kebijakan BUMN: Menghadapi Era AFTA dan APEC 2010." Jurnal Keuangan dan Moneter. Jakarta: Badan Kebijakan Fiskal.

Sedlak, M and Roberts, I. (1991). "An Inevitable Part of Economic Reform: Demonopolization and the Development of Economic Competition." Soviet and Eastern European Foreign Trade Journal, 27(2). http://www.jstor.org/stable/2774925.

\section{Regulations:}

Constitution of Indonesian Republic of 1945.

Decision of Constitution Court No. 002/PUU-I/2003, Judicial Review of Law No. 22 of 2001 concerning Oil and Gas.

Decision of Constitution Court No. 36/PUU-X/2012. Judicial Review of Law No. 22 of 2001 concerning Oil and Gas.

Decision of Ministry of State-Owned Enterprises Indonesia Republic No. PER1/MBU/07/2017, concerning Organization and Good Corporate Ministries of SOEs.

Law No. 19 of 2003 concerning State-Owned Enterprises.

Law No. 25 of 2009 concerning Public Utility.

Law No. 40 of 2007 concerning Limited Company

\section{Miscellaneous:}

Swasono, S. (2008). "Kesokoguruan Ekonomi Rakyat dan Triple-Co. Harian Umum Suara Pembaharuan, Jakarta, 14 Juli 2008. 